\title{
Competency Identification of Officials in Omani Civil Service for Improving Government Performance
}

\author{
Ahmed Albalushi \\ PhD student \\ Ashraf Zaidan \\ Fakhrul Adabi Bin Abdul Khadir \\ Dr., Senior Lecture \\ Human Development Department \\ University of Malaya \\ Malaysia
}

\begin{abstract}
This study aims to identify the relationship between core competencies (teamwork, Results Driven, Communication, Customer Focus, Creative \& Innovation) and leadership competencies (thinking Strategic, Leading Change, leading people, building relationships, Improving Performance) and its impact on improving government performance in the civil service units in the Sultanate of Oman. The descriptive approach was used by the study tool "Questionnaire" through a sample of (332) employees of permanent jobs in the government units, the analysis of data and hypothesis testing by (SPSS). The results of the study showed a strong and positive correlation between core competencies, leadership and improved government performance in civil service units, The study recommends that these competencies should be applied in various human resources management practices and placed within an integrated framework that is compatible with the future vision of Oman 2040, which seeks to develop competencies and improve the effectiveness of government performance.
\end{abstract}

Keywords: Competency Management, Competencies, Civil Service, Government Performance.

\section{1- Introduction}

As indicated previously, that the civil service reform is one of the most difficult development reforms, but efforts by governments and international organizations, researchers seeking to overcome these difficulties, bridging research gaps, development solutions, various scientific methodologies, and continuing. The civil service reform needs a long time, to the vision and a clear strategy, cooperation between the various government agencies, in addition to supporting the adoption and applied research projects (Albalushi, Ahmed, et al, 2019). Where is the reform of the civil service of the most difficult development reforms, but it is now essential for the sustainability of the public sector because the application of the principles of competency in the civil service gives the individual the ability to achieve the best results, which reflected positively on the well-being of society(UNDP, 2015, 2010). Confirms De Beeck \& Hondeghem, (2010) that is expected when the civil servants apply competencies in their work, the result is to be the effective performance, which in turn leads to the achievement of the objectives of the government. And thus, the positive impact on the economic growth of the countries when adhering to the principles of competency in the civil service (Cortázar, JC, 2016).

A recent study by the (Korn Ferry, 2018) Entitled: Global Talent Crisis The Global Talent crunch By studying the financial implications resulting from the lack of qualified owners at three different time levels 2020.2025, 2030 (20) of the economies of developed and developing countries where the study results that there is a major crisis looming enormous shock will affect the institutions all over the world, it is expected a shortage of skilled labor by the year 2030, it has a talent crisis lead to a change in the global balance of economic power by 2030 and must governments take different methods and approaches to meet the expected shortfall in talent. Research suggests that States that are managed by skilled enjoying high economic growth rates, this confirmed it as well World Development Report 1997 That the application of Merit In the civil service helps to bring staff with high quality (UNDP, 2015).

The translation of those directives of the Sultan of Oman came to be prepared for future vision" Oman 2040" To be assimilated to all sectors and forward-looking and focus of the vision: develop competencies and improve the effectiveness of governance and institutional performance (Oman 2040, nd). 
The participants in the Arab Conference on Public Administration (EURO MENA), entitled: Modernization of human resource management and Performance of public Organizations, held in Muscat on October, recommended the need to shift from traditional human resources management to modern patterns As the competencies Management and Human capital Management with the aim of improving performance in the public sector (Alharthy, 2016).

He stressed (Gangani, et al., 2006) that the use of the Competency method as the basis for the management and development of human resources has become widespread and is gaining more international practices, therefore it must be more research on the applicability of Competencies in various HR functions.

In view of the foregoing, the importance of the management and development of competencies in the public sector in the present day, the public administration in the Sultanate of Oman represented in the civil service pay attention to the development of its human resources and the introduction of modern methods that will increase productivity and improve the institutional performance reflected Positively on government performance in generally. Therefore, this article will discuss competencies by focusing on Core Competency \& Leadership Competency for civil servants and their relationship to improving government performance in Omani civil service units using the questionnaire as a study tool.

\section{Literature Review}

One of the most major challenges for the management of human resources based on competency is that the concept of competency is precisely defined and can be understood in different ways (Sienkiewicz, 2014). The term competency is scientifically and practically both for its association with a wide range and variety of meanings and terms ability, aptitude, capability, competence, effectiveness, skill This can be a term attributed to individuals, or groups, or institutions, because of the Tapping in scientific definitions of competency, it is impossible to determine a specific definition agreed upon, however, it can be explained through scientific or process that followed the researcher to build the scientific theory of competency goals (Weinert, 1999) (Delamare, Deist, and Winterton, 2007). Where it can be returned the term competency in the literature to the seventies, there are many different definitions of competency (Benayoune, 2017).

According to the theoretical assumptions, the competency-based management is a new trend in human resources management and is one of the advantages of building competency management systems in the possibility of integrating all areas of human resources management because of a methodology based on competency (Sienkiewicz, 2014). Confirms S. Beeck \& Hondeghem,(2010) that competency management is more than just identifying competencies and using them in different processes of human resources, as they need to be dynamic on the organization as a whole and should be competency management becomes a way of thinking for their integration into human resources activities and systematically, and in line with the organization, vision and strategic message and implemented throughout the organization.

Studies and applications based on efficiency since that time and then gained to the present acceptance among the academic work and the business community have gone through three stages of development (Kupczyk, 2014): 1.2 The first stage: Competencies Individuals Both researchers (White 1959; McClelland 1973; Boyatzis 1982; Woodruffe 1992; Spencer, Spencer 1993; McCracking 1998)

a. The second phase: Competencies Models For each of the (Mansfield 1996; McLagan 1997; Lucia, Lepsinger 1999; Rothwell, Lindholm 1999).

b. Third level: Core Competency Identifying, For each of the (Prahalad, Hamel 1990; Ulrich, Lake 1991; Gallon, Stillman, Coates 1995; Coyne, Hall, Clifford 1997; Rothwell, Lindholm 1999; Delamare, Winterton 2005).

Figure 1 shows an integrated system for the management of competencies in the organization, where vertical integration refers to human competency's coherence with the vision and strategy of the organization, as well as human resources policies, therefore should be selected competencies, organize, develop and evaluate even contribute to the achievement of the organization's goals.(S. Beeck \& Hondeghem, 2010). 


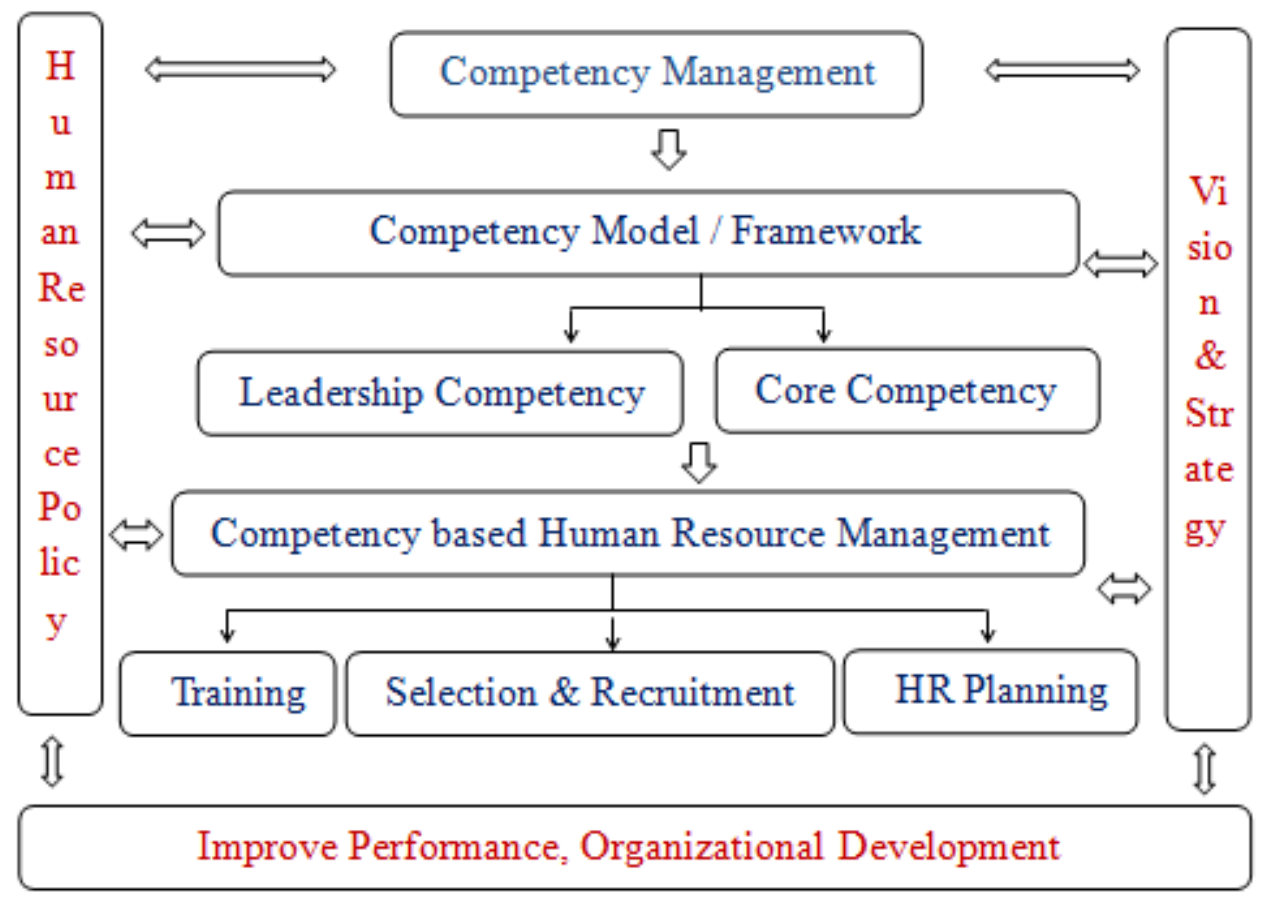

Figure 1. Competency Management System (L. Spencer, \&S. Spencer, 1993), (Laakso-Manninen \& iitala, 2007), (S. Beeck \& Hondeghem, 2010), (Campion \& Odman, 2011).

Uses competency model Synonym competency framework It is a descriptive tool that includes skills, knowledge, personality traits and abilities and behavior are clear and detailed staff in the organization, is considered very necessary to achieve strategic objectives and business successfully, the framework for assessing the quality of human capital from the perspective of the organization's needs, therefore the successful application of the concept of competencies in the organization conditional on providing process solutions field-based human resources management competency through competency models or frameworks (Hamid, 2014), (Sienkiewicz, 2014) .

This requires undertaking various measures can be classified into four categories, namely, (determining competency, competency assessment, gain competency, the use of competency) Initially, the institution you need to discover the competencies possessed by either the individual or organizational level, because they serve as a basis for the development of future talent, more importantly, what are the competencies they need to improve institutional performance. (Rousku, 2014).

In the past few years, human resources have gradually evolved and focused on the theme of core Competency Identifying, where many studies have indicated that the concept of core competency is widely applied in human resources management activities, Barney \& Wright (Lado \& Wilson) have indicated that Organizations can only grow with their resources but implement the strategy and support it through Core competencies with various human resources activities (Yang, Bai-chuan, et al, 2006). Clardy (2008) explains that there are three strategic human resource development roles in supporting core competencies, namely:

- Participation in the strategic planning process, through the provision of educational resources on the strategy and core competencies.

- Identify and describe core competencies by studying and collecting core competencies using multiple maps and evaluation procedures, describing core competencies and inventorying them with current competency levels.

- Maintaining the core competencies by clarifying learning methods and development processes, linking core competencies with the performance management system, integrating them with culture and values.

The research carried out by Hamel \& Prahalad (1990) emphasizes that the leadership and management process of the enterprise should focus on identifying, developing and exploiting the foundation's core knowledge and competencies, suggesting that the first task of competency management is to provide a detailed and accurate definition of competencies. The OECD report (2016) noted that the most important core competencies contained in the competency frameworks and models of the Organization for Economic Cooperation and Development (OECD) countries are (28) efficient, there are (6) competencies considered to be the highest in the hierarchy (Values and ethics, leadership, Achieving results, Strategic Thinking, Communication, Teamwork). 
In this study we collected the most important Core competencies at both (OPM., 2018; MPM., 2018; Benayoune, a. 2017; FAHR., 2017; OECD, 2016; OCHRO, 2015; Rousku, A. 2014; Sienkiewicz, Ł. 2014; Kim, S., \& Jung, H. W.2010; Beeck, S., \& Hondeghem, A. 2010).

We found that there are (5) Core competencies similar in organizations with different labels as in table (1). Sober scientific studies show that many competencies are highly correlated, which means that they may reflect the same concepts but with different names (Cook, 2009).

Table 1 Core competencies

\begin{tabular}{|c|c|c|c|}
\hline $\mathrm{NO}$ & Core competencies & Definition & Frequency \\
\hline CC 1 & Teamwork & $\begin{array}{l}\text { Ability to work collectively and in a team spirit } \\
\text { between different departments and } \\
\text { organizational departments in order to achieve } \\
\text { the objectives of the Organization. }\end{array}$ & 8 \\
\hline $\mathrm{CC} 2$ & Results Driven & $\begin{array}{l}\text { Ability to achieve specific and measurable } \\
\text { performance results while maintaining } \\
\text { effectiveness and excellence in achieving } \\
\text { results. }\end{array}$ & 6 \\
\hline $\mathrm{CC} 3$ & Communication & $\begin{array}{l}\text { The ability to express and communicate ideas } \\
\text { and opinions using the official means and } \\
\text { channels of communication, and in a positive } \\
\text { way. }\end{array}$ & 5 \\
\hline $\mathrm{CC} 4$ & Customer focus & $\begin{array}{l}\text { Ability to understand the needs of auditors from } \\
\text { within and outside the organization and strive } \\
\text { to provide services professionally and } \\
\text { professionally. }\end{array}$ & 5 \\
\hline CC 5 & Creative \& Innovation & $\begin{array}{l}\text { The ability to generate innovative ideas and } \\
\text { solutions for different business processes and } \\
\text { methods, and the ability to suggest new creative } \\
\text { methods that improve performance. }\end{array}$ & 3 \\
\hline
\end{tabular}

A study of the World Bank and experts involved in the performance of the public sector that senior government positions require skills and competencies, therefore requires efforts in the polarization and keep them in accordance with the competency management system, has allocated some countries and the independence of that category under the name Senior Executive Civil Service As in America, Canada, Britain, South Korea, Australia, the choice of appointment system and a competitive open document on merit (Lafuente, M. et al, 2012 ). A study OECD (2015): That half of the EU member states have a competency framework for senior civil servants.

Leadership Competency is an important and required senior management capacity to make government management more effective, an important variable that leads to enhanced performance in public sector institutions, a comparative study on the management competencies of senior public sector managers in the United States of America. United Kingdom, Canada, Australia and France (Charih, Mohamed, et al., 2007). A report by Center for Creative Leadership (2016) referred to the skills and competencies needed by leaders in government by analyzing the leadership effectiveness data of more than 16,000 managers in the government sector who attended the Centre's leadership development programs, the results indicated the most important of these skills and competencies are Leading Employees, Change Management, Building and mending relationships, participative management .

In this study, we collected the most important Leadership competencies at both (OPM., 2018; MPM., 2018; Benayoune, a. 2017; FAHR., 2017; OECD, 2016; OCHRO, 2015; Rousku, A. 2014; Sienkiewicz, Ł. 2014; Kim, S., \& Jung, H. W.2010; Beeck, S., \& Hondeghem, A. 2010)

We found that there are (5) Leadership competencies similar in organizations in different designations as in table.(2) 
Table 2 Leadership competencies

\begin{tabular}{|c|c|c|c|}
\hline $\mathrm{NO}$ & Leadership competencies & Definition & Frequency \\
\hline $\begin{array}{l}\mathrm{LC} \\
1\end{array}$ & Thinking Strategic & $\begin{array}{l}\text { The ability to develop a clear vision for the } \\
\text { future and to link strategic objectives to the } \\
\text { priorities of action. }\end{array}$ & 7 \\
\hline $\begin{array}{l}\mathrm{LC} \\
2\end{array}$ & Leading Change & $\begin{array}{l}\text { The ability to respond promptly to critical } \\
\text { events, analyze them, identify areas for } \\
\text { change, and engage and commit individuals } \\
\text { and task forces changing. }\end{array}$ & 6 \\
\hline $\begin{array}{l}\mathrm{LC} \\
3\end{array}$ & Leading People & $\begin{array}{l}\text { The ability to motivate, encourage, develop } \\
\text { and empower employees and provide them } \\
\text { with a suitable working environment that } \\
\text { meets their career needs and meets their future } \\
\text { aspirations. }\end{array}$ & 6 \\
\hline $\begin{array}{l}\text { LC } \\
4\end{array}$ & Building Relationships & $\begin{array}{l}\text { The ability to build and consolidate working } \\
\text { relationships with the relevant parties with the } \\
\text { institution, negotiate with them and develop } \\
\text { relationships with a positive impact on the } \\
\text { performance of the institution. }\end{array}$ & 5 \\
\hline $\begin{array}{l}\text { LC } \\
5\end{array}$ & Improving Performance & $\begin{array}{l}\text { The ability to create a high-performance } \\
\text { organizational culture that is goal-oriented and } \\
\text { results-based. }\end{array}$ & 4 \\
\hline
\end{tabular}

In this framework model (see Figure2) the competency construct is divided into Core Competency and Leadership Competency, the objective to understand if a positive relationship between Core Competency Identifying and Leadership Competency Identifying with Improving Government Performance as perceived by the Omani Civil Service employees.

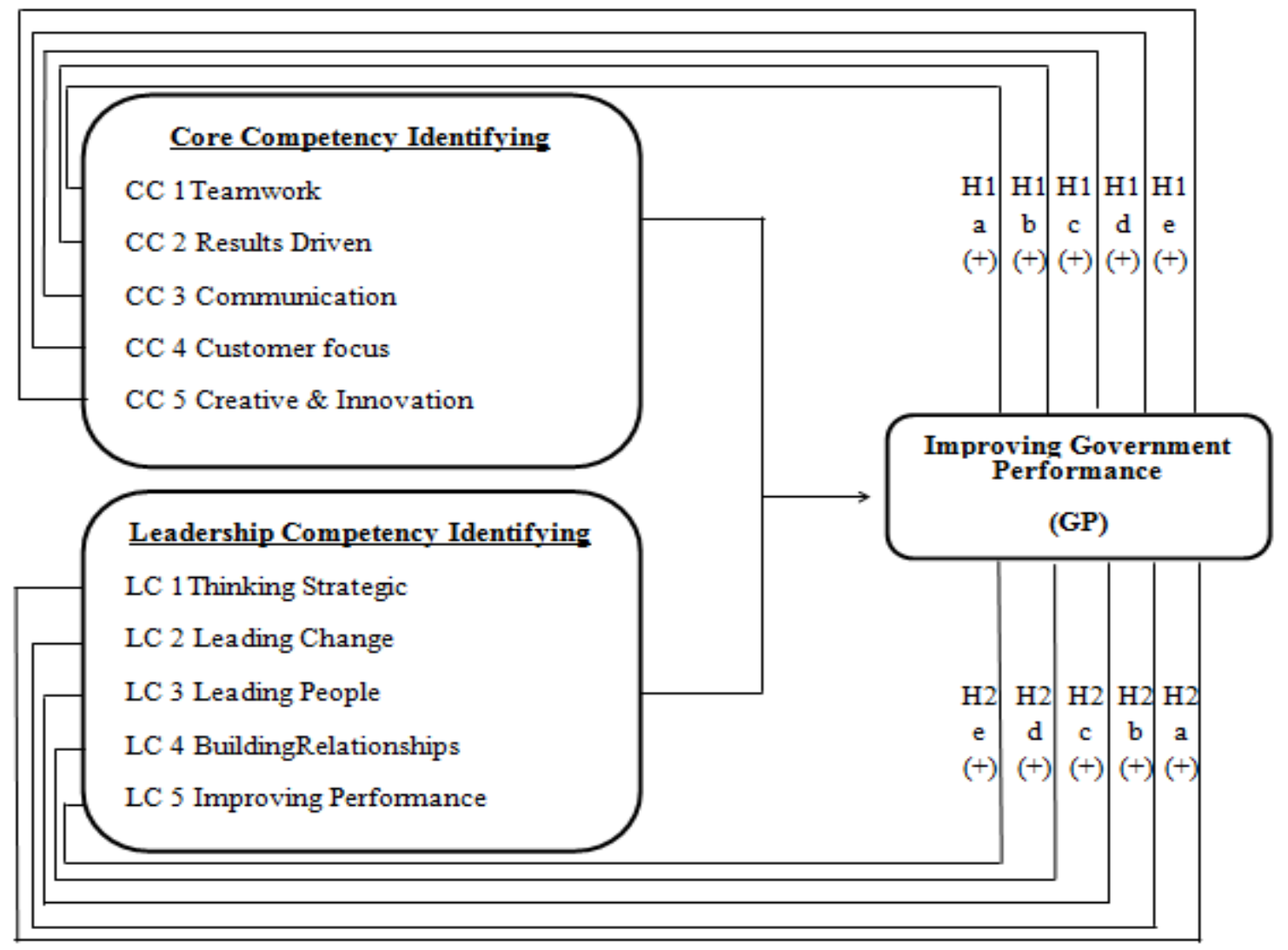

Figure.2 Proposed Model for Research 


\section{2-Research Hypothesis}

Based on the above theoretical model the following hypotheses are proposed:

Hypothesis 1: Core Competency as defined (Teamwork, Results Driven, Communication, Customer focus, Creative \& Innovation) have a positive relationship with Improving Government Performance as perceived by the Omani Civil Service employees.

Hypothesis 2: Leadership Competency as defined (Thinking Strategic, Leading Change, Leading People, Building Relationships, Improving Performance) has a positive relationship with Improving Government Performance as perceived by the Omani Civil Service employees.

\section{3- Research Methodology}

The study adopts the survey method as a research design in the conduct of this work. The population of this study consists of all the Omani Civil Service employees in Muscat Governorate Sultanate of Oman, the highest percentage was (26.7\%) (40997)of the total. This can be ascribed to the fact that most government units are located there (Ministry of Civil Service, 2018). Those organizations that apply the Civil Services Law, according to the statistical report issued by the Ministry of Civil Services (2018), the total number of these organizations is 39.

There are many approaches to calculate the sample size, for example, use a formula developed by Krejcie and Morgan (1970). Accordingly, for this study, the desired level of precision would be $+/-5 \%$. The sample size is calculated based on Krejcie and Morgan (1970) formula for a confidence level of $95 \%$. In summary for this study, the required sample size (S) is 380 based on the provided population size ( $\mathrm{N}=40997)$ confidence level of $95 \%$ and the precision level of 5\%. The data for this research was collected through questionnaire. The questionnaires were randomly distributed to (400) full time working adults who worked at Civil Service Units in Muscat by e-mail and by hand and the response rate was $83 \%$ (332).

A survey was administered in Oman during the period of 2019 by using a structured questionnaire that was developed based on the previous studies carried out by (OPM., 2018; MPM., 2018; Benayoune, A. 2017; FAHR., 2017; OCHRO., 2015; Rousku, A. 2014; Sienkiewicz, Ł. 2014; Kim, S., \& Jung, H. W.2010; Beeck, S., \& Hondeghem, A. 2010) . The questionnaire, which was used to assess to what degree respondents agreed or disagreed with the measurement items, employed a 5-point Likert-type scale, ranging from strongly disagree (1) to strongly agree (5). The data were then analyzed using the Statistical Package for the Social Sciences (SPSS).

\section{4- Results}

\section{Sample Characteristics}

A total of 400 surveys were distributed and 332 surveys were collected, giving a response rate of $83 \%$. Table 3 shows the profile of the respondents. The majority of the respondents were bachelor's degrees $(42.1 \%)$ and Postgraduate $(40.3 \%)$. Most respondents were between 31 and 40 years old $(49.7 \%)$, and the respondents having experience of more than 15 years in the public sector were $(44.5 \%)$. The table also shows that $(57.2 \%)$ of the respondents were Middle Management, and most respondents of Civil Service Units were concentrated in the Ministry of Education and Ministry of Health, representing (25.5\%) of the sample total. 
Table 3 Descriptive Statistics for Respondents

\begin{tabular}{llll}
\hline Variables & Category & Frequency & Percentage \\
Educational background & Non-graduate & 20 & 6 \\
& Diploma & 38 & 11.4 \\
& Bachelor & 140 & 42.1 \\
& Postgraduate & 134 & 40.3 \\
Age (years) & $20-30$ & 32 & 9.6 \\
& $31-40$ & 165 & 49.7 \\
Years of experience & $41-50$ & 115 & 34.6 \\
& $>50$ & 20 & 6 \\
& $<5$ years & 13 & 3.9 \\
Management levels & 11-15 & 105 & 31.6 \\
& 15 and above & 66 & 19.8 \\
& Top Management & 148 & 44.5 \\
Civil Service Units & Middle Management & 23 & 6.9 \\
& Executive Management & 190 & 57.2 \\
& Ministry of Education & 119 & 35.8 \\
& Ministry of Health & 52 & 13 \\
& Ministry of Endowments & 50 & 12.5 \\
& Ministry of Agriculture & 31 & 7.7 \\
& Ministry of Municipalities & 33 & 8.2 \\
& Ministry of Social Development & 38 & 7 \\
& Ministry of Manpower & 26 & 9.5 \\
& Ministry of Justice & 13 & 6.5 \\
& Ministry of Civil Service & 19 & 4.2 \\
& Ministry of Environment & 17 & 4.7 \\
& Supreme Council Planning & 10 & 2.5 \\
& Institute of Public Administration & 15 & 3.8 \\
\hline
\end{tabular}

\subsection{Reliability coefficients}

The data was subjected to reliability analysis using Cronbach Alpha. The generally agreed Cronbach's Alpha is $(0.60)$ as an acceptable reliability coefficient (Sekaran, 2005). Therefore, as indicated above the overall Cronbach Alpha of the instrument is (0.98) and the entire scale variables used in the research instrument fall within acceptable limits. Table 4 features the reliability of the main variables.

Table 4 Reliability coefficients for main variables.

\begin{tabular}{lll}
\hline Variables & Items & Cronbach Alpha \\
Core Competency Identifying & 5 & .97 \\
Leadership Competency Identifying & 5 & .98 \\
Improving Government Performance & 6 & .96 \\
\hline
\end{tabular}

\subsection{Descriptive Statistics of the Variables}

The results of table (5) indicate the arithmetic averages and standard deviations of the degree of approval of the three main variables by the members of the study sample, as it is clear from the table that the level of measurement of study variables in general in terms of relative importance is high, the results show that the dimensions of Core Competency Identifying came in the first place in terms of importance and average arithmetic (3.84) and standard deviation (. 70), the dimensions related to Leadership Competency Identifying were second, average arithmetic (4.47) and standard deviation (. 73), while the dimensions Improving Government Performance came in the last place with an arithmetic average (3.98) and a standard deviation (. 92). 
Table 5 Descriptive Statistics of the Variables

\begin{tabular}{llllll}
\hline Variables & Constructs & Mean & Std. & $\begin{array}{l}\text { Relative } \\
\text { Importance }\end{array}$ & Rank \\
Core Competency & & $\mathbf{4 . 8 4}$ & $\mathbf{. 7 0}$ & High & $\mathbf{1}$ \\
Identifying & & & & \\
CC 1 & Teamwork & 4.58 & .64 & High & 1 \\
CC 2 & Results Driven & 4.37 & .70 & High & 5 \\
CC 3 & 4.40 & .72 & High & 4 \\
CC 4 & Communication & 4.53 & .75 & High & 3 \\
CC 5 & Customer focus & 4.55 & .69 & High & 2 \\
Leadership Competency & Creative \& Innovation & $\mathbf{4 . 4 7}$ & $\mathbf{. 7 3}$ & High & $\mathbf{2}$ \\
Identifying & & & & & \\
LC 1 & & 4.50 & .71 & High & 2 \\
LC 2 & Thinking Strategic & 4.46 & .77 & High & 3 \\
LC 3 & 4.52 & .73 & High & 1 \\
LC 4 & Leading Change & 4.44 & .73 & High & 5 \\
LC5 & Leading People & 4.45 & .71 & High & 4 \\
Improving Government & Building Relationships & $\mathbf{3 . 9 8}$ & $\mathbf{. 9 2}$ & High & $\mathbf{3}$ \\
Performance & Improving Performance & & & & \\
GP 1 & & 4.46 & .70 & High & 1 \\
GP 2 & Competency Framework & 4.45 & .73 & High & 2 \\
GP 3 & Performance Measurement Law & .85 & High & 3 \\
GP 4 & Performance Measurement Model & 4.34 & 1.07 & High & 4 \\
GP 5 & Performance Measurement Center & 4.10 & 1.07 & 6 \\
GP 6 & Performance Measurement Approach & 3.27 & 1.10 & Moderate & 6 \\
\hline
\end{tabular}

\subsection{Correlation Analysis}

Table 6 firstly looks at the relationship between Core Competency Identifying and Improving Government Performance of the Omani Civil Service employees. Secondly, the table shows the relationship between Leadership Competency Identifying and Improving Government Performance of the Omani Civil Service employees. The hypotheses $(\mathrm{H} 1-\mathrm{H} 2)$ are analyzed using Pearson Correlation. As shown in Table (CC) has very positive a significant correlation relationship at $0.947(\mathrm{p}<.000)$ with the (GP).Within Core competencies, the CC4 is the most highly correlated at $0.969(\mathrm{p}<.000)$ with GP, followed by CC3 at $0.961(\mathrm{p}<.000)$, CC5 at $0.927(\mathrm{p}<.000)$. From the same, we can further note that (LC) also has very positive a significant correlation relationship at $0.976(\mathrm{p}<.000)$ with the (GP).On the other hand, within the Leadership competencies, the LC2 is the most highly correlated at $0.953(\mathrm{p}<.000)$ with GP, followed by LC1 at 0.909 ( $\mathrm{p}<.000), \mathrm{LC} 4$ at $0.886(\mathrm{p}<.000)$. Given the below data there is significant support for the purposed hypotheses and as such, we fail to reject them. 
Table 6 Relationship of CC, LC, with the GP

\begin{tabular}{|c|c|c|c|c|c|c|c|c|c|c|c|}
\hline $\begin{array}{l}\text { Variables } \\
\text { D. Variables }\end{array}$ & GP & $\mathrm{CC} 1$ & $\mathrm{CC} 2$ & $\mathrm{CC} 3$ & $\mathrm{CC} 4$ & CC5 & $\mathrm{LC} 1$ & LC2 & LC3 & $\mathrm{LC} 4$ & LC5 \\
\hline GP & 1 & & & & & & & & & & \\
\hline In. Variables & & & & & & & & & & & \\
\hline $\mathrm{CC} 1$ & $.824^{* *}$ & 1 & & & & & & & & & \\
\hline $\mathrm{CC} 2$ & $\begin{array}{l}.850 * \\
*\end{array}$ & $.963 * *$ & 1 & & & & & & & & \\
\hline $\mathrm{CC} 3$ & $\begin{array}{l}.961 * \\
*\end{array}$ & $.856^{* *}$ & $\begin{array}{l}.882 * \\
*\end{array}$ & 1 & & & & & & & \\
\hline $\mathrm{CC} 4$ & $\begin{array}{l}.969 * \\
*\end{array}$ & $.839 * *$ & $\begin{array}{l}.875^{*} \\
*\end{array}$ & $\begin{array}{l}.960 * \\
*\end{array}$ & 1 & & & & & & \\
\hline $\mathrm{CC} 5$ & $\begin{array}{l}.927 * \\
*\end{array}$ & $.878 * *$ & $\begin{array}{l}.913 * \\
*\end{array}$ & $\begin{array}{l}.937^{*} \\
*\end{array}$ & $\begin{array}{l}.954 * \\
*\end{array}$ & 1 & & & & & \\
\hline LC1 & $\begin{array}{l}.909 * \\
*\end{array}$ & $.898 * *$ & $\begin{array}{l}.925^{*} \\
*\end{array}$ & $\begin{array}{l}.943^{*} \\
*\end{array}$ & $\begin{array}{l}.928 * \\
*\end{array}$ & $\begin{array}{l}.965 * \\
*\end{array}$ & 1 & & & & \\
\hline LC2 & $\begin{array}{l}.953^{*} \\
*\end{array}$ & $.852 * *$ & $\begin{array}{l}.880 * \\
*\end{array}$ & $.970^{*}$ & $\begin{array}{l}.972 * \\
*\end{array}$ & $.955^{*}$ & $.945^{*}$ & 1 & & & \\
\hline LC3 & $\begin{array}{l}.885^{*} \\
*\end{array}$ & $.916^{* *}$ & $\begin{array}{l}.928 * \\
*\end{array}$ & $\begin{array}{l}.919^{*} \\
*\end{array}$ & $\begin{array}{l}.897 * \\
*\end{array}$ & $\begin{array}{l}.938 * \\
*\end{array}$ & $\begin{array}{l}.965^{*} \\
*\end{array}$ & $\begin{array}{l}.919 * \\
*\end{array}$ & 1 & & \\
\hline $\mathrm{LC} 4$ & $\begin{array}{l}.886^{*} \\
*\end{array}$ & $.917 * *$ & $\begin{array}{l}.942 * \\
*\end{array}$ & $\begin{array}{l}.914^{*} \\
*\end{array}$ & $\begin{array}{l}.900 * \\
*\end{array}$ & $\begin{array}{l}.943 * \\
*\end{array}$ & $\begin{array}{l}.963^{*} \\
*\end{array}$ & $\begin{array}{l}.924 * \\
*\end{array}$ & $\begin{array}{l}.980^{\circ} \\
*\end{array}$ & 1 & \\
\hline LC5 & $\begin{array}{l}.886^{*} \\
*\end{array}$ & $.913 * *$ & $\begin{array}{l}.927 * \\
*\end{array}$ & $\begin{array}{l}.910^{*} \\
*\end{array}$ & $\begin{array}{l}.895^{*} \\
*\end{array}$ & $\begin{array}{l}.939 * \\
*\end{array}$ & $\begin{array}{l}.961 * \\
*\end{array}$ & $\begin{array}{l}.909 * \\
*\end{array}$ & $\begin{array}{l}.989 \\
*\end{array}$ & $.967 *$ & 1 \\
\hline
\end{tabular}

Notes: **. Correlation is significant at the 0.01 level (2-tailed).

\section{Discussion}

The previous findings, as in table (3), indicating that the scientific background of the study sample was a campaign (Bachelor \& Postgraduate), which resulted in the results being obtained objectively, the government was keen to identify the scientific competencies in various professional occupations. The majority of the sample are young people who are active, wanting to demonstrate their abilities, to move towards new competencies, which in turn are reflected in improved performance in the civil service. Most members of the sample have more than 15 years of practical experience and are therefore familiar with the laws and administrative procedures relating to the organization of personnel in the civil service. They are also at the Middle Management level and this is a good indicator that this level is well versed in the upper and lower levels and is qualified to hold leadership positions in the future according to the leadership competencies in which they have expressed their opinion.

All members of the sample agree on the importance of Core Competency in improving government performance in civil service units as in table (5) in the following order of importance (Teamwork, Creative \& Innovation, Customer Focus, Communication, Results Driven) These results are consistent with the OECD report (2016), with competencies defined in the competency framework or model of governmental organizations and referred to in table (1).

All members of the sample also agree on the importance of Leadership Competency in improving government performance in the civil Service units as in table (5) in the following order of importance (Leading people, thinking Strategic, Leading Change, Improving Performance, Building relationships).

These results are consistent with the Centre for Creative Leadership (2016) report, with the competencies defined in the competency framework or model of governmental organizations and referred to in table (2).

The results of the study showed the positive relationship and strong correlation between the core competencies and the improvement of government performance as in table (6), when the civil service units select and recruit employees and evaluate their performance, promotion and training according to the core competencies mentioned above they get Effective institutional performance, which is reflected in its entirety on government performance. The results indicated that the highest core competency in a strong performance relationship is customer focus and is consistent with the study Ullah.A, Ajmal.M, Aslam.W(2016), is consistent with the reference in Hamel \& Prahalad (1990) to the importance of customer requirements when preparing core competencies within the organization. 
The results of the study also showed the positive relationship and strong correlation between leadership competencies and the improvement of government performance as in table (6), when the civil service units select and recruit employees and evaluate their performance, promotion and training in accordance with the leadership competencies listed above they get Effective institutional performance, which is reflected in its entirety on government performance. In addition, organizational development, improving institutional performance and achieving competitive advantage require effective management leadership that possesses a range of competencies as described above. The results indicated that the highest core competency in a strong performance relationship is Leading Change and is consistent with the study (Battilana, Julie, et al., 2010).

\section{5- Conclusion}

The research of competency is one of the hot issues in the area of HRM at present (Liu, Hui.et al,2014). This study is considered important for the government units in Oman, especially during the next phase of the vision of new Oman 2040, which is due to be launched the next year 2020, which, through one of its axes, aimed at developing competencies and improving the effectiveness of government performance. It provides a range of core competencies and leadership that, if applied professionally in various human resources functions such as selection, appointment, performance evaluation and training, will improve institutional performance. We hope that government decisionmakers will need to develop an integrated framework of core and leadership competencies for civil servants following clear and specific indicators linked to various human resource practices.

The construction of an integrated system for the management of competencies is important to move to a talent management system steps, if implemented properly it will achieve the best results of government performance (Albalushi, Ahmed, et al, 2019).

\section{Acknowledgments}

The authors would like to thank the Institute of Public Administration Sultanate of Oman for providing the research grant (grant number: IPA 335/2019) and all parties involved in this research.

\section{References}

Albalushi, Ahmed, et al. (2019). Competency Management in the Context of Omani Civil Service Reform \& Development. International Business Research, 12(4), 76-89, https://doi.org/10.5539/ibr.v12n4p76.

Alharthy, Effat. (2016). EURO-MENA Dialogues Report. AlEdari Journal, Institute of Public Administration, 147,135146.

Battilana, Julie, et al. (2010). Leadership competencies for implementing planned organizational change. The Leadership Quarterly, 21, 422-438, doi: 10.1016/j.leaqua.2010.03.007.

Beeck, S., \& Hondeghem, A. (2010). Competency Management in the Public Sector : Three Dimensions of Integration Paper for the IRSPM Conference 2010. IRSPM Conference 2010.

Benayoune, A. (2017). Copetency-based framework: The benefits and the challenges. International Journal of Management and Applied Science, 3(9), 6-11.

Campion, M. A, \& Odman, R. B. (2011). Doing competencies well: Best practice in competency modelling. Personnel Psychology, 64, 225-262. https://doi.org/10.1111/j.1744-6570.2010.01207.x.

Charih, Mohamed, et al. (2007). The Management Competencies of Senior Managers: A Look at Some OECD Countries. In Excellence and Leadership in the Public Sector: The Role of Education and Training, New York: United Nations, 25-43, https://publicadministration.un.org/publications.

Clardy, Alan.(2008).The strategic role of Human Resource Development in managing core competencies, Human Resource Development International, 11:2, 183-197, DOI: 10.1080/13678860801932998.

Cook, Mark.(2009). Personnel Selection: Adding Value Through People. John Wiley \& Sons.

De Beeck, S. O., \& Hondeghem, A. (2010). Managing Competencies in Government: State of the Art Practices and Issues at Stake for the Future. State of the Art Practices and Issues at Stake for the Future, 1-129. Retrieved from papers2://publication/uuid/7571753A-B9CD-4DE5-B552-96B435DBD8AE.

Delamare, F., Le D., \& Jonathan, W. (2007). What Is Competence? Journal Human Resource Development International, 8(1), 27-46. https://doi.org/10.1080/1367886042000338227.

FAHR. (2017). Federal Authority For Government Human Resources Strategic. Emirates. https://www.fahr.gov.ae/Portal/Userfiles/Assets/Documents/187b791b.pdf .

Hamid, A. (2014). Development of an HR Practitioner Competency Model and Determining the Important Business Competencies : An Empirical Study in Malaysia. International Journal of Management Excellence 3(2), 446461. https://doi.org/10.17722/ijme.v3i2.167. 
Gangani, N. T., McLean, G. N., \& Braden, R. A. (2006). A Competency-Based Human Resource Development Strategy. PerformanceImprovementQuarterly,19,127-139. https://doi.org/ 10.1111/j.1937-8327.2006.tb00361.x.

Kupczyk, T. (2014). Competencies of management Staff in the Knowledge-Based Economy.pdf.

Kim, S., \& Jung, H. W. (2010). The competency Management in the Korean National Government. K.U. Leuven, PublicManagementhttps://soc.kuleuven.be/io/onderzoek/project/files/hrm27-country-report-korea.pdf.

Krejcie, R. V., \& Morgan, D. W. (1970). Determining sample size for research activities. Educ Psychol Meas.

Korn Ferry.(2018). Future of work: The Global Talent Crunch,1-52, https://infokf.kornferry.com/rs/494-VUC482/images/pdf.

Laakso-Manninen, R., \& iitala, R. (2007). Competence management and human resources development: A theoretical framework for understanding the practices of modern Finnish organisations. HAAGA-HELIA Research. Retrieved from http://www.haaga-helia.fi/sites/default/files/Kuvat-ja-liitteet/Palvelut/Julkaisut/hrdweb.pdf.

L. Spencer, \& S. Spencer. (1993). Competence at Work: Model for Superior Performance. John Wiley \& Sons, New York.

Lafuente,M. Manning, N. Watkins, J. (2012).International Experiences with Senior Executive Service Cadres. Global Expert Team on Public Sector Performance (PSP GET), The World Bank, April, P 1-16, http://siteresources.worldbank.org/EXTGOVANTICORR/Resources/3035863-

1285601351606/GET_Note_Recently_Asked_Questions_Senior_Executive_Services.pdf.

Liu, Hui.et al.(2014). Empirical Analysis of the Relationship between HR Professionals' Competency and Enterprise Performance. International Conference on Management Science and Management Innovation.

MCS. (2015). competency Framework- Guideline. Ministry of Civil Service, Kingdom of Saudi Arabia, August, https://www.mcs.gov.sa

MPM. (2018). Public Human Resource Management at a Glance 2018. Ministry of Personnel Management. South Korea, http://www.mpm.go.kr/english/news/Multimedia/ebook/hrm/hrm2018/.

Ministry of Civil Service. (2018). The Annual Statistics of Civil Service Employees [Electronic version]. Issue No.47, May, 1-116, from http://portal.mocs.gov.om/pdf_files/stat2017.pdf.

OECD. (2017). Staff performance management in Government at a Glance 2017. OECD Publishing. Paris, DOI: https://doi.org/10.1787/gov_glance-2017-46-e

OECD. (2016). Skills for A High Performing Civil Service. Public Governance Reviews, 1-14, https://www.oecd.org/gov/pem/Skills-Highlights.pdf.

OECD. (2015). Dominican Republic : Human Resource Management for Innovation in Government.OECD Public Governance Reviews, 1-372.

http://www.oecd.org/publications/dominican-republic-human-resource-management-for-innovation-ingovernment-9789264211353-en.htm

OCHRO. (2015). Key Leadership Competencies: Examples of Effective and Ineffective Behaviors.Office of the Chief Human Resources Officer. Treasury Board of Canada Secretariat, June.Oman 2040. (n.d) Improving GovernanceEffectiveness. https://2040.om/en/governance-and-institutional-performance/.

Prahalad, C.K.\& Hamel, Gary.(1990).The Core Competence of the Corporation.Harvard Business Review, May-June, 79-91.

Pulakos, E. D. (2004). Performance Management: A roadmap for developing, implementing and evaluating performance management systems. The Society for Human Resource Management(SHRM), https://www.shrm.org/hr-today/trends-and-forecasting/special-reports-and-expertviews/Documents/Performance-Management.pdf.

Rousku, A. (2014). Competence Identification Assessment \& Development : Study Merivaara Oy. Master's Degree programs in International Business Administration Thesis, Lahti University of Applied Sciences, P1-88, https://www.theseus.fi/bitstream/handle/10024/85126/Rousku_Anu.pdf?sequence=1.

Sienkiewicz, Ł. (2014). Competency-based human resources management The lifelong learning perspective. Educational Research Institute.

Sekaran, U. (2005). Research Methods for Business, a Skill Building Approach. New York: JohnWiley \& Sons, Inc.

Ullah.A, Ajmal.M, Aslam.W.(2016). Study of Relationship between Customer Focus and Organizational Performance in the Telecommunication Organizations of Pakistan. Information and Knowledge Management, 6(12), 38-45, https://pdfs.semanticscholar.org/afdb/070aa5940d9f27964d95dabb5b0a6c57a377.pdf.

UNDP. (2015). Meritocracy for Public Service Excellence. United Nations Development Programme. Global Centre for Public Service Excellence, Singapore, \& Regional Hub of Civil Services in Astana, Kazakhstan, http://www.undp.org/content/dam/undp/library/capacity-

development/English/Singapore\%20Centre/Meritocracy-PSE.pdf. 
UNDP. (2010). Motivating Civil Servants for Reform and Performance. United Nations Development Programmed, https://orbi.uliege.be/bitstream/2268/37467/1/Motivating\%20Civil\%20Servants\%20for\%20Reform\%20and\%2 OPerformance.pdf.

Velsor, Ellen, et al. (2016). Creating Tomorrow's Government Leaders: An Overview of Top Leadership Challenges and How They Can Be Addressed. Center for Creative Leadership, 1-14, https://www.ccl.org/wpcontent/uploads/2016/09/creating-government-leaders-and-addressing-challenges-center-for-creativeleadership.pdf.

Weinert, F. E. (1999) Concepts of Competence, Definition and Selection of Competencies, April, Retrieved from http://citeseerx.ist.psu.edu/viewdoc/download?doi=10.1.1.111.1152\&rep=rep1\&type=pdf.

Yang, Bai-Chuan, et al. (2006).On establishing the core competency identifying model A value-activity and process orientedapproach,IndustrialManagement\&DataSystems.106(1), 60-80, http://www.emeraldinsight.com/Insight/ ViewContentServlet?Filename=/published/emerald-fulltextarticle/pdf/0291060104.pdf. 